
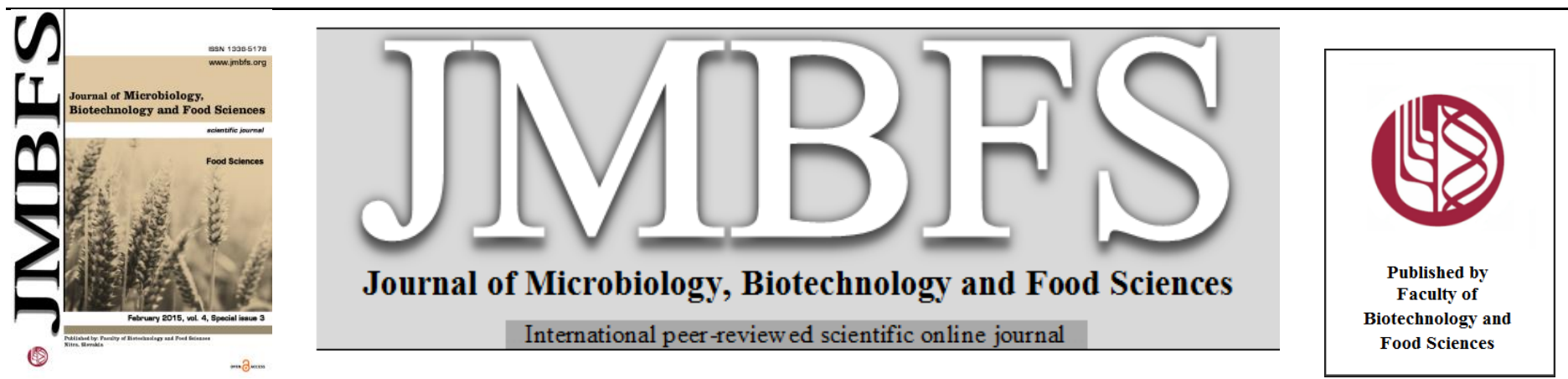

\title{
THE EVALUATION OF NICKEL, CHROMIUM, LEAD AND MERCURY CONTENT IN SWEET CORN
}

\author{
Miriama Kopernická*, Tomáš Tóth, Luboš Harangozo, Beáta Volnová, Petra Kavalcová, Ádám Elek
}

Address(es): Mgr. Miriama Kopernická

${ }^{1}$ Slovak University of Agriculture in Nitra, Faculty of Biotechnology and Food Sciences, Department of Chemistry, Tr. A. Hlinku 2, 94976 Nitra, Slovak Republic, phone number: +421376414376.

*Corresponding author:m.kopernicka@gmail.com

doi: 10.15414/jmbfs.2015.4.special3.87-90

\section{ARTICLE INFO}

Received 12.11. 2014

Revised 20.11. 2014

Accepted 21. 11. 2014

Published 2. 2. 2015

$\underline{\text { Regular article }}$

open $O$ access

\section{ABSTRACT}

In the framework of monitoring, we have focused on the analysis of the levels of nickel, chromium, lead and mercury in 9 samples of sweet corn (frozen and canned) from the commercial network of the Slovak Republic. Homogenised samples of sweet corn were mineralized using microwave digestion unit MARS X-press and next analysed by atomic absorption spectrometer VARIAN 240 FS for tested metal concentration, excluding mercury which was was determined by automatic mercury analyser AMA 254.Nickel content in all samples was in the range of $0.376-0.556 \mathrm{mg} \cdot \mathrm{kg}^{-1}$, chromium content was $0.088-0.546 \mathrm{mg} \cdot \mathrm{kg}^{-1}$, lead content was $0.054-0.146$ mg. $\mathrm{kg}^{-1}$ and mercury content was $0.000013-0.011458 \mathrm{mg} \cdot \mathrm{kg}^{-1}$. The measured values have been compared with the limit values set out legislation for the maximum quantity of hazardous elements according to the Food Code of the Slovak Republic. From the point of view of the sanitary evaluation, the content of nickel, chromium, lead and mercury were not exceeded in either sample.

Keywords: Food contamination, sweet corn, nickel, chromium, lead, mercury,

\section{INTRODUCTION}

Sweet corn (Zea mays amylacea saccharata) is one of the oldest foods in the world, about 5,000 years old. It comes from the American continent and was imported by discoverers of America to Europe. First of all corn was grown in Spain. At the end of the 15th century became the cultivation of corn significant development. Since the beginning of the 16th century it began to expand throughout Europe (Gay, 1984). In terms of the world's economy can be corn considered as the most important feed material and human nutrition (Jurášek, 1997). The fruit of corn is a grain or achene from the botanical point of view. It may be a variety of shapes and colors. Endosperm consists of $80-84 \%$ of grain weight and contains starch (Ryšavá et al., 2004). The corn provides an important raw material for the processing industry, especially for food, construction, chemicals and pharmaceuticals (Pospíšil, 2002). The corn is very beneficial for health due to its composition. The main component of grain corn is starch $(60-$ $70 \%$ ). Corn also contains proteins in an average $10 \%$, vitamin A, E, B and also vitamin $\mathrm{C}, \mathrm{D}$ and $\mathrm{K}$ in trace amounts.

Heavy metals from natural and anthropogenic sources have harmful effects on soil, reduce nutritional, technological and sensory value of the plant and affects the health of animals and people. The sources of heavy metals are transport, industry as well as agriculture. Soil is a fundamental component of environment.
The importance of care and preservation of safe and hygienic land that produces food and feed is enhanced by its difference from the other components of the environment (Ducsay et al., 2000). The phytotoxic effects depend on the concentration and amount of an acceptable form of heavy metals in the soil solution, the speed of the element from a solid phase to a liquid solution, the physical and chemical characteristics of the soil but also the type of cultivated plants. In the potentially toxic elements even slight increases in concentrations of these elements operates phytotoxic in terms of quality but also quantity harvested production (Kulich, 1994; Gábriš et al., 1998; Kočík, 1991; Ducsay, 1995). Heavy metals are at certain concentrations in the organism toxic or lethal. Through the food chain are significantly great risk to plants, animals and people. The excess of heavy metals in the body produces free radicals that destroy organic molecules in the body (Zeng et al., 2011).

The aim of our work was to determine the concentration of heavy metals in sweet corn available in the commercial network of Slovak Republic.

\section{MATERIAL AND METHODS}

Sweet corn samples commonly available in commercial network in Slovak republic was tested to determine the contents of the risk elements (nickel, chromium, lead, mercury) in the frozen $(n=3)$ and canned $(n=6)$ sweet corn. Description and characteristics of the analysed samples was given in table 1 .

Table 1 Description and characteristics of the analysed samples

\begin{tabular}{cccc}
\hline $\begin{array}{c}\text { Sample } \\
\text { number }\end{array}$ & Product name & Packing/weight & Country of origin \\
\hline 1 & Novo - fruct & $210 \mathrm{~g}$ & Slovak Republic \\
2 & Jamar & $400 \mathrm{~g}$ & Poland \\
3 & Mňam - Mňam & $425 \mathrm{~g}$ & China \\
4 & Znojmia & $340 \mathrm{~g}$ & Czech Republic \\
5 & Bonduelle - Sweet corn & $425 \mathrm{~g}$ & Hungary \\
6 & Bonduelle - Super sweet corn & $400 \mathrm{~g}$ & Hungary \\
7 & Iglo & $325 \mathrm{~g}$ & Austria \\
8 & Klassik & $450 \mathrm{~g}$ & Belgium \\
9 & Cukrík & $350 \mathrm{~g}$ & Unknown \\
\hline
\end{tabular}


Determination of heavy metals in grain of sweet corn (excluding mercury) Samples $(1 \mathrm{~g})$ of sweet corn were mineralized by wet road using microwave digestion unit MARS X-press. The metal contents were determined by Flame Atomic Absorption Spectrometry AA240FS Varian (Varian, Australia). Repetition of the experiment was three and the average value was used in the analysis of measurement.

\section{Determination of mercury in grain of sweet corn}

The total mercury concentration was determined in the homogenized corn samples (0.005-0.01 g) using a cold - vapour AAS analyser AMA 254 (Altec, Czech Republic) with a detection limit of 0.5 ng.g, atomic absorption spectrophotometer dedicated for the direct determination of mercury in solid and liquid samples.

The results of analyses were compared with the limit values that define the Food Code of the Slovak Republic (No. 608/3/2004 - 100 setting maximum levels for contaminants in foods). For statistical evaluation of results was used the program STATGRAFICS Plus 5.1 to process gained data (Multifactor ANOVA, LSD test).

\section{RESULTS AND DISCUSSION}

The lowest $\mathrm{Ni}$ content was measured in the sample No. 3 with a value of 0.376 mg.kg $\mathrm{kg}^{-1}$ and the highest was measured in the sample No. 9 with a value of 0.556 mg. $\mathrm{kg}^{-1}$, which was not exceeded the limit value $2.500 \mathrm{mg} \cdot \mathrm{kg}^{-1}$, defined in the Food Code of SR. Results are shown in the figure 1.

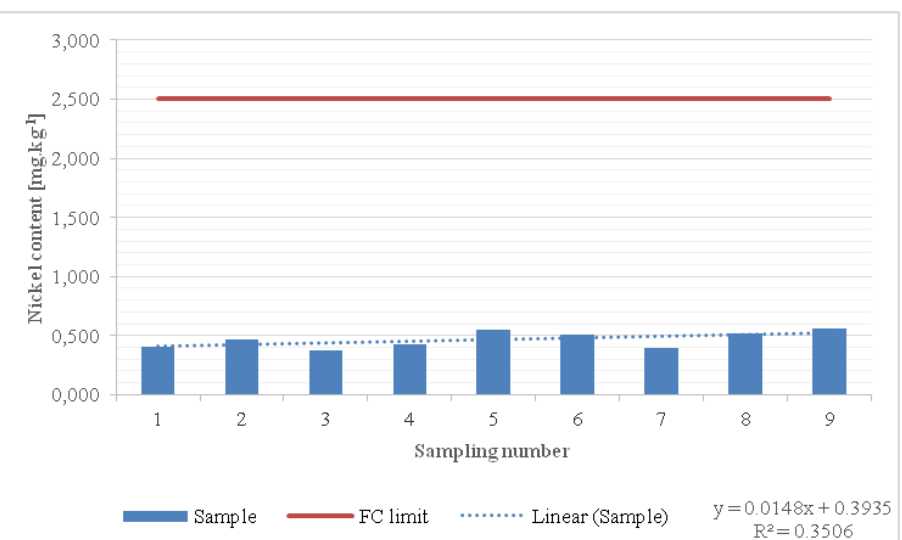

Figure 1 Nickel content in samples of sweet corn $\left(\mathrm{mg} \cdot \mathrm{kg}^{-1}\right)$

The lowest $\mathrm{Cr}$ content was measured in the sample No. 2 with a value of 0.088 mg. $\mathrm{kg}^{-1}$ and the highest was measured in the sample No. 5 with a value of 0.546 mg.kg ${ }^{-1}$, which was not exceeded the limit value $4.000 \mathrm{mg} \cdot \mathrm{kg}^{-1}$ (Food Code). Results are shown in the figure 2.

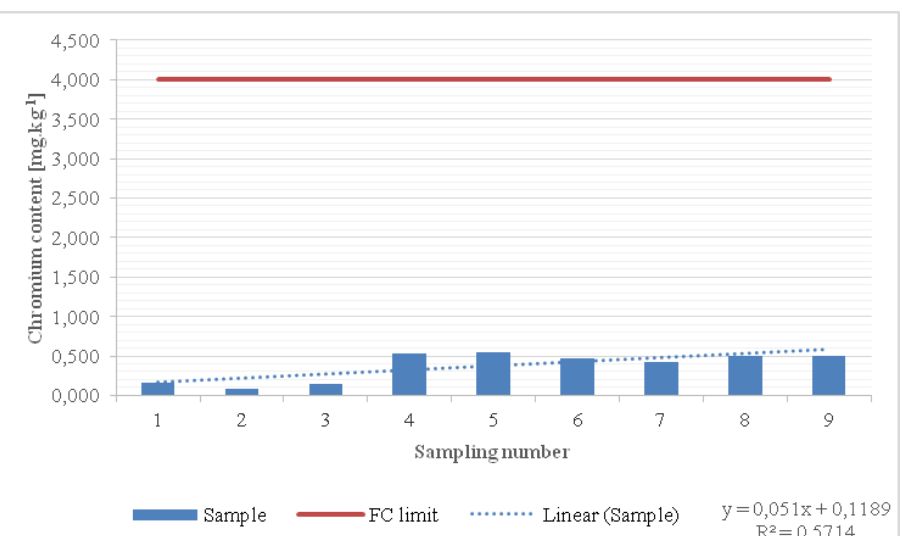

Figure 2 Chromium content in samples of sweet corn $\left(\mathrm{mg} \cdot \mathrm{kg}^{-1}\right)$

The lowest $\mathrm{Pb}$ content was measured in the sample No. 6 with a value of 0.054 mg.kg ${ }^{-1}$ and the highest in the sample No.2 with a value of $0.146 \mathrm{mg} \cdot \mathrm{kg}^{-1}$ was measured, which was not exceeded the limit value $1.000 \mathrm{mg}^{\mathrm{kg}}{ }^{-1}$ (Food Code). Results are shown in the figure 3.

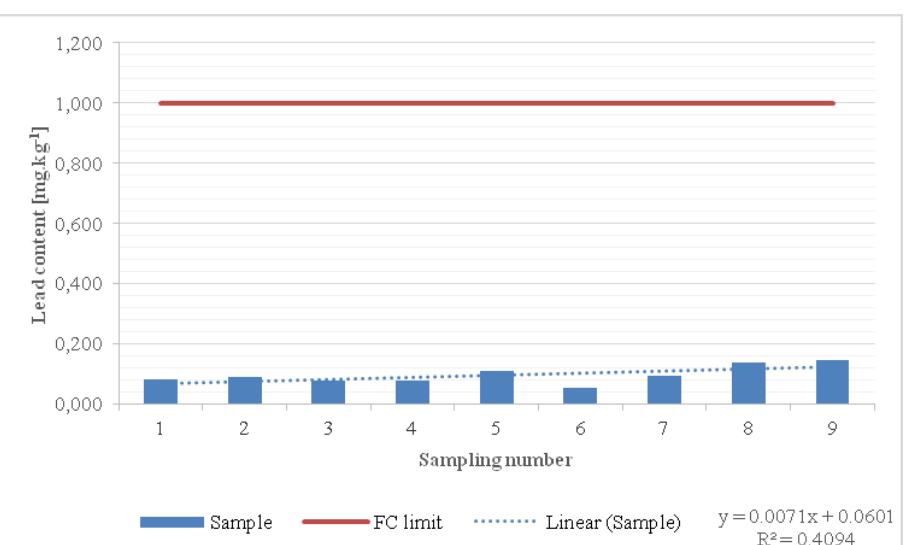

Figure 3 Lead content in samples of sweet corn $\left(\mathrm{mg} \cdot \mathrm{kg}^{-1}\right)$

The lowest $\mathrm{Hg}$ content was measured in the sample No. 9 with a value of $0.000013 \mathrm{mg} \cdot \mathrm{kg}^{-1}$ and the highest in the sample number 2 with a value of $0.011458 \mathrm{mg} \cdot \mathrm{kg}^{-1}$ was measured, which was not exceeded the limit value 0.050 $\mathrm{mg} \cdot \mathrm{kg}^{-1}$ (Food Code). Results are shown in the figure 4.

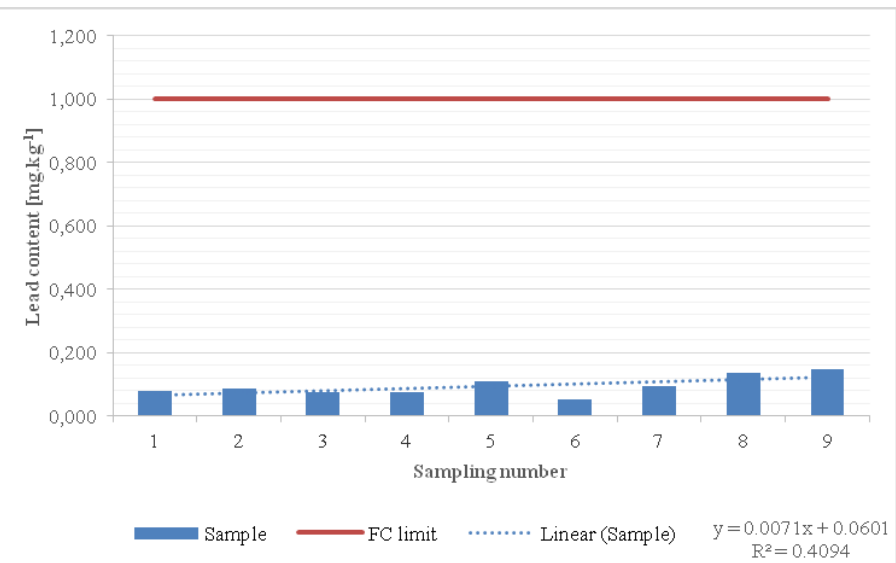

Figure 4 Mercury content in samples of sweet corn $\left(\mathrm{mg} \cdot \mathrm{kg}^{-1}\right)$

In all samples was not exceed the total content limit values of monitored heavy metals. Between samples No. 1 and 7 , then 6 and 8 and finally 5 and 9 were not significant differences $(\mathrm{P}>0,05)$ in the concentration of nickel. Between samples No. 1 and 3, then 8 and 9 and finally 4 and 5 were not significant differences in the concentration of chromium ( $P>0,05)$, between samples No. 1, 2, 3 and 4, then 6 and 8 and finally 5 and 9 were not significant differences in the concentration of lead $(\mathrm{P}>0,05)$ and in the case of the concentration of mercury between samples number 4 and 5 were not significant differences (Tab 2).

We also observed strong statistical significant correlations for $\mathrm{Ni}, \mathrm{Cr}$ and $\mathrm{Pb}$ contentin samples (Tab 3).

We also observed strong statistical significant correlation between $\mathrm{Ni}, \mathrm{Cr}$ and $\mathrm{Pb}$ contentWith increasing $\mathrm{Ni}$ content, the content of $\mathrm{Cr}$ increase. Based on the increasing value of $\mathrm{Pb}$ concentration also increase $\mathrm{Ni}$ content. $\mathrm{Ni}$ content was not statistically significant influenced by $\mathrm{Hg}$ content. (Tab 4).

$\mathrm{Cr}$ content was significantly influenced by $\mathrm{Ni}$ and $\mathrm{Hg}$ content. $\mathrm{Cr}$ content was not statistically significant influenced by $\mathrm{Pb}$ content. With increasing $\mathrm{Cr}$ content, the content of $\mathrm{Ni}$ increase. Based on the increasing value of $\mathrm{Hg}$ concentration also increase $\mathrm{Cr}$ content ( $\mathrm{Tab} 5$ ).

$\mathrm{Pb}$ content was significantly influenced by $\mathrm{Ni}$ content, but not by $\mathrm{Cr}$ and $\mathrm{Hg}$ content. With increasing $\mathrm{Pb}$ content, the content of $\mathrm{Ni}$ increase (Tab 6).

$\mathrm{Hg}$ content was negatively influenced only by $\mathrm{Cr}$ content, with increasing $\mathrm{Hg}$ content, the content of $\mathrm{Cr}$ decrease ( $\mathrm{Tab} 7)$. 
Table 2 Level of the concentration significance of $\mathrm{Ni}, \mathrm{Cr}, \mathrm{Pb}$ and $\mathrm{Hg}$ in sweet corn

\begin{tabular}{|c|c|c|c|c|}
\hline \multirow{2}{*}{ Sample } & \multicolumn{4}{|c|}{ Heavy metal content } \\
\hline & $\mathrm{Ni}\left[\mathrm{mg} \cdot \mathrm{kg}^{-1}\right]$ & $\mathrm{Cr}\left[\mathrm{mg} \cdot \mathrm{kg}^{-1}\right]$ & $\mathrm{Pb}\left[\mathrm{mg} \cdot \mathrm{kg}^{-1}\right]$ & Hg [mg.kg $\left.{ }^{-1}\right]$ \\
\hline 1 & $0,402 \mathrm{~b}$ & $0,161 \mathrm{~b}$ & $0,080 \mathrm{~b}$ & $0,001385 \mathrm{c}$ \\
\hline 2 & $0,470 \mathrm{~d}$ & $0,088 \mathrm{a}$ & $0,088 \mathrm{bc}$ & $0,011458 \mathrm{~h}$ \\
\hline 3 & $0,376 \mathrm{a}$ & $0,150 \mathrm{~b}$ & $0,075 \mathrm{~b}$ & $0,002313 \mathrm{f}$ \\
\hline 4 & $0,429 \mathrm{c}$ & $0,530 \mathrm{f}$ & $0,076 \mathrm{~b}$ & $0,001523 \mathrm{~d}$ \\
\hline 5 & $0,546 \mathrm{f}$ & $0,546 \mathrm{f}$ & $0,109 \mathrm{~d}$ & $0,001498 \mathrm{~d}$ \\
\hline 6 & $0,509 \mathrm{e}$ & $0,470 \mathrm{~d}$ & $0,054 \mathrm{a}$ & $0,000419 \mathrm{~b}$ \\
\hline 7 & $0,398 \mathrm{~b}$ & $0,426 \mathrm{c}$ & $0,094 \mathrm{c}$ & $0,007316 \mathrm{~g}$ \\
\hline 8 & $0,521 \mathrm{e}$ & $0,501 \mathrm{e}$ & $0,137 \mathrm{e}$ & $0,002033 \mathrm{e}$ \\
\hline 9 & $0,556 \mathrm{f}$ & $0,494 \mathrm{e}$ & $0,146 \mathrm{e}$ & $0,000013 \mathrm{a}$ \\
\hline Mean & $0,467 \pm 0,068$ & $0,374 \pm 0,185$ & $0,095 \pm 0,030$ & $0,003 \pm 0,004$ \\
\hline $\mathrm{HD}_{0,05}$ & 0,0188607 & 0,0161931 & 0,0131514 & 0,0000994 \\
\hline
\end{tabular}

Table 3 Pearson correlation coefficient between samples and heavy metal content

\begin{tabular}{|c|c|c|}
\hline \multicolumn{2}{|c|}{ Parameter } & \multirow{2}{*}{ Correlation coefficient $(r)$} \\
\hline Dependent variable & Independent variable & \\
\hline \multirow{4}{*}{ Sample } & $\mathrm{Ni}$ & $0,5892 * *$ \\
\hline & $\mathrm{Cr}$ & $0,7551 * *$ \\
\hline & $\mathrm{Pb}$ & $0,6311^{* *}$ \\
\hline & $\mathrm{Hg}$ & $-0,3004$ \\
\hline
\end{tabular}

Table 4 Pearson correlation coefficient between Ni and other heavy metal content

\begin{tabular}{lll}
\hline \multicolumn{1}{c}{ Parameter } & \multirow{2}{*}{ Correlation coefficient (r) } \\
\hline \multirow{2}{*}{$\mathrm{Ni}$} & Independent variable & $0,5763^{* *}$ \\
& $\mathrm{Cr}$ & $0,5816^{* *}$ \\
& $\mathrm{~Pb}$ & $-0,2854$ \\
\hline *strong statistical significant of the correlations, *statistical significant of the correlations
\end{tabular}

**strong statistical significant of the correlations, *statistical significant of the correlations

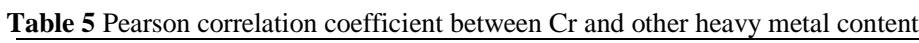

\begin{tabular}{llc}
\hline \multicolumn{1}{c}{ Parameter } & \multirow{2}{*}{ Correlation coefficient (r) } \\
\cline { 1 - 2 } $\mathrm{Cr}$ & Independent variable & $0,5763^{* *}$ \\
& $\mathrm{Ni}$ & 0,3605 \\
$*$ *strong statistical significant of the correlations, *statistical significant of the correlations & $-0,5208^{* *}$ \\
\hline
\end{tabular}

**strong statistical significant of the correlations, *statistical significant of the correlations

Table 6 Pearson correlation coefficient between $\mathrm{Pb}$ and other heavy metal content

\begin{tabular}{lll}
\hline \multicolumn{1}{c}{ Parameter } & \multirow{2}{*}{ Correlation coefficient (r) } \\
\cline { 1 - 2 } Dependent variable & Independent variable & $0,5816^{* *}$ \\
$\mathrm{~Pb}$ & $\mathrm{Ni}$ & 0,3605 \\
& $\mathrm{Cr}$ & $-0,1146$ \\
\hline * & $\mathrm{Hg}$ &
\end{tabular}

**strong statistical significant of the correlations, *statistical significant of the correlations

Table 7 Pearson correlation coefficient between $\mathrm{Hg}$ and other heavy metal content

\begin{tabular}{lll} 
& \multicolumn{1}{c}{ Parameter } & \multicolumn{2}{c}{ Correlation coefficient (r) } \\
\hline Dependent variable & Independent variable & $-0,2854$ \\
$\mathrm{Hg}$ & $\mathrm{Ni}$ & $-0,5208^{* *}$ \\
& $\mathrm{Cr}$ & $-0,1146$ \\
\hline
\end{tabular}

Because heavy metal treatment activates different metabolic processes in different developmental parts of the root, the potential benefits of biotechnological approaches in terms of protecting the most sensitive parts of the root should be evaluated in the context of this metabolic distribution. The ability to protect the growth zones of roots from heavy metal poisoning could potentially greatly reduce the impact of heavy metal toxicity on crops (Ovečka, Takáč, 2014). According to published data heavy metal concentrations observed for corn were within the normal range (Lavado et al., 2001). The heavy metal level in sweet corn was in the same order of magnitude as that obtained in Australian soils (Oliver et al., 1998).

\section{CONCLUSION}

To evaluate of the quality of frozen and canned sweet corn can be concluded, that the excess hygienic sanitary limit in terms of heavy metals have not been found even in the case of nickel, chromium, lead or in the case of mercury. Analyzed samples of sweet corn were therefore suitable for consumption and does not pose any real risk of nickel, chromium, lead and mercury in the human body.

Acknowledgments: This work was supported by the project VEGA 1/0630/13 and KEGA 014SPU-4/2013.

\section{REFERENCES}

DUCSAY, L., TOMAN, R., KOČÍK, K. 2000. Rizikové faktory potravového ret’azca človeka (t’ažké kovy $\mathrm{v}$ pôdach a rastlinách). Nitra : Slovenská polnohospodárska univerzita, $143 \mathrm{~s}$. ISBN 80-7137-796-1.

DUCSAY, L. 1995. Redukcia tvorby biomasy a jej kvalitatívne zmeny pri expozícii $\mathrm{As}, \mathrm{Cd}, \mathrm{Pb}$ a Mo, Mn, Sr. Nitra : DPP, $185 \mathrm{~s}$.

FOOD CODE of the Slovak Republic No. 608/3/2004 - 100 setting maximum levels for contaminants in food.

GÁBRIŠ, L. et al. 1998. Ochrana a tvorba životného prostredia v pol'nohospodárstve. Nitra : Slovenská pol’nohospodárska univerzita, $461 \mathrm{~s}$.

GAY, J. P. 1984. Le cycle du mais. Physiologie du mais. Paris : INRA, 1-11.

JURÁŠEK, P. 1997. Kukurica - bohyn̆a mayov. Rolnícke noviny, 45(1-73/1997), 8-9. ISSN 0231-6617.

KOČÍK, K. 1991. Fytotoxicita As, Pb a Cd (Xi. konf. MVP) Nitra : Slovenská pol'nohospodárska univerzita, 99-106.

KULICH, J. 1994. Rizikové prvky v agroekologických podmienkach Hornej Nitry. Nitra : Slovenská pol'nohospodárska univerzita, $106 \mathrm{~s}$.

LAVADO, R. S., PORCELLI, C. A., ALVAREZ, R. 2001. Nutrient and heavy metal concentration and distribution in corn, soybean and wheat as affected by 
different tillage systems in the Argentine Pampas. Soil and tillage research. 62 55-60. http://dx.doi.org/10.1016/s0167-1987(01)00216-1

OLIVER, D. P., TILLER, K. G., ALSTON, A. M., COZENS, G. D., MERRY, R. H. 1998. Effects of soil $\mathrm{pH}$ applied cadmium concentration in wheat grain. Autralian journal of soil research, 36, 571-583. http://dx.doi.org/10.1071/s97106 OVEČKA, M., TAKÁC̆, T. 2014. Managing heavy metal toxicity stress in plants: Biological and biotechnological tools. Biotechnology advances. 32, 73-86. http://dx.doi.org/10.1016/j.biotechadv.2013.11.011

POSPÍŠIL, R. PAČUTA, V. 2002. Základy rastlinnej výroby. Nitra : Slovenská pol'nohospodárska univerzita, $143 \mathrm{~s}$. ISBN 80-7137-976-X

RYŠAVÁ, B., BANIČOVÁ, J., MAZÚR, M., MÚDRY, P. 2014. Kukurica biológia, pestovanie a využívanie. Nitra : Slovenská pol'nohospodárska univerzita, 114 s. ISBN 80-8069-387-0.

ZENG, F., ALI, S. ZHANG, H., OUYANG, Y., QIU, B., WU, F. ZHANG, G. 2011. The influence of $\mathrm{pH}$ and organic mater content in paddy soilon heavy metal availability and their uptake by rice plants. Environmental pollution, 84-91. ISSN 0269-7491. http://dx.doi.org/10.1016/j.envpol.2010.09.019

PIERGIOVANNI, A.R., LAGHETTI, G., PERRINO, P. 1996. Characteristics of Meal from Hulled Wheats (Triticum dicoccon Schrank and T. spelta L.): An Evaluation of Selected Accessions. Cereal Chemistry, 73 (6), 732 - 735.

RANHOTRA, G.S. 1994. Wheat: Contribution to world food supply and human nutritional. Wheat Production, Properties and Quality, London : Chapman \& Hall, 12 - 24. http://dx.doi.org/10.1007/978-1-4615-2672-8_2

RUIBAL - MENDIETA, N.L., DELACROIX, D.L., MEURENS, M. 2002. A comparative analysis of free, bound and total lipid content on spelt and winter wheat wholemeal. Journal of Cereal Science, $35(3), 337-342$ http://dx.doi.org/10.1006/jcrs.2001.0434

ŠPÁNIK, F., REPA. Š., ŠIŠKA, B. 1996. Klimatické a fenologické pomery Nitry (1961 - 1990). Bratislava : Slovenská bioklimatologická spoločnost' SAV 60.

ZOHARY, D., HOPF, M. 1994. Domestication of Plants in the Old World: The origin and Spread of Cultivated Plants in West Asia, Europe and the Nile Valley. Oxford : Clarendon Press, 279 p. ISBN 019 - 85489-6. http://dx.doi.org/10.1017/s0016672300034558 